\title{
Yapısal ve Psikolojik Güçlendirmenin Kariyer Tatmini ve Yenilikçi İş Davranışı Üzerine Etkisi ${ }^{1}$
}

Mihriban Cindiloğlu Demirer ${ }^{2}$

Yapısal ve Psikolojik Güçlendirmenin Kariyer Tatmini ve Yenilikçi İş Davranışı Üzerine Etkisi

\section{Öz}

Bu çalışmanın amacı yapısal ve psikolojik güçlendirmenin kariyer tatmini ile yenilikçi iş davranışı üzerindeki etkisini belirlemektir. Araştırma hipotezlerini test etmek amacıyla, üretim işletmelerinde beyaz yakalı olarak görev yapan çalışanlardan anket yöntemi ile veriler toplanmıştır. Analiz sonuçları incelendiğinde, yapısal ve psikolojik güçlendirmenin kariyer tatmini ve yenilikçi iş davranışı üzerinde pozitif bir etkiye sahip olduğu tespit edilmiştir. Bu çalışmada aynı zamanda iki model karşılaştırma yapılarak incelenmiştir. Birinci model, yapısal güçlendirmenin kariyer tatmini ve yenilikçi iş davranışı arasındaki ilişki üzerinde psikolojik güçlendirmenin aracılık etkisinin olup olmadığıdır. İkinci model, yapısal ve psikolojik güçlendirmenin yenilikçi iş davranışı üzerinde kariyer tatmininin aracılık etkisinin olup olmadığıdır. Modelleri test etmek amacıyla hiyerarşik regresyon analizi yapılmıştır. Bu analizler sonucunda psikolojik güçlendirmenin ve kariyer tatmininin değişkenler arasında aracılık rolü olduğu tespit edilmiştir.

Anahtar Kelimeler: Yapısal Güçlendirme, Psikolojik Güçlendirme, Kariyer Tatmini, Yenilikçi İş Davranışı
Effects of Structural and Psychological Empowerment on Career Satisfaction and Innovative Work Behavior

\section{Abstract}

The purpose of study is to determine the effect of structural and psychological empowerment on career satisfaction and innovative work behavior. In order to test the research hypotheses, data were collected from the white-collar employees in the production businesses by survey method. As a result of the analysis, it is found that structural empowerment and psychological empowerment has a positive effect with career satisfaction and innovative work behavior. In this study, two models were examined by comparison. The first model is whether psychological empowerment has an mediator variable effect on the relationship between structural empowerment and career satisfaction and innovative work behavior. The second model is whether career satisfaction has an mediator variable effect on the relationship between structural and psychological empowerment and innovative work behavior. In order to test the models, hierarchical regression analysis was performed. As a result of these analyzes, it was found that psychological empowerment and career satisfaction had an mediator role among the variables.

Keywords: Structural Empowerment, Psychological Empowerment, Career Satisfaction, Innovative Work Behavior

\section{Giriş}

Rekabetin her geçen gün kendini daha da hissettirdiği iş dünyasında örgütler, çalışanlarından yeni ve farklı fikirler beklemek, çalışanlarına başarılı olmalarını sağlayacak imkânlar sunmak ve onları örgütleriyle bütünleştirmek zorundadır. Güçlendirme, bu zorunluluğu yerine getirmede yöneticilere yardımcı olacak önemli kavramlardan birisidir. Bu çalışmada güçlendirme, çalışanları güçlendirmeyi temel alan yapısal ve psikolojik güçlendirme şeklinde incelenmiştir. Yapısal güçlendirme çalışanların, örgüt içerisinde başarıya ulaşabilmeleri için yöneticilerin onlara fırsat tanıyacakları ortamları hazırlamaları şeklinde tanımlanabilir. Psikolojik güçlendirme çalışanlar tarafından, yapısal güçlendirmenin algılanıp algılanmadığını açıklamaktadır. Bu güçlendirme tarzları olan yapısal ve psikolojik güçlendirme kariyer tatmini ve yenilikçi iş davranışını etkilemekte midir?

\footnotetext{
${ }^{1}$ Bu çalışmanın bir bölümü 20-21 Nisan 2019 tarihinde Saraybosna'da düzenlenen 3rd International Conference on Social Researches and Behavioral Sciences de sözlü bildiri olarak sunulmuştur.

${ }^{2}$ Dr. Öğr. Üyesi, Hitit Üniversitesi, iỉBF, Uluslararası Ticaret ve Lojistik Yönetimi Bölümü, mihribancindiloglu@hitit.edu.tr, Yazar ORCID bilgisi: https://orcid.org/0000-0002-3530-2215.
} 
İ̧ hayatında yer alan bireyler için kariyer, yaşamlarının bir parçası haline gelmektedir. Çünkü birey örgüt ortamında yaşamının uzunca bir bölümünü geçirmektedir. Bunun yanı sıra kariyer, çalışanın gelişmesi, örgüt ortamında bir statü, güç, yaptığı işte söz sahibi olma, karar verebilme, saygınlık gibi önemli kazanımları da bireyin elde etmesini sağlamakta olduğunu söyleyebiliriz. Çalışanın bu olumlu ilerleme sürecini yaşayabilmesi için örgüt ortamında buna yönelik bir yapısal güçlendirme sürecinin var olması gerekmektedir. Çalışanlarda kariyer tatminin oluşması ancak bu sürecin ilerlemesi ile gerçekleşebilir. Kariyer tatmini, bir çalışanın kariyeri ile ilgili farklı hedeflere ve başarılara ulaşma yönündeki ilerlemesini değerlendirmesidir. Yapısal güçlendirmenin yanı sıra çalışanın bu güçlendirme sürecini psikolojik olarak algılaması da elbette önem arz etmektedir. Yenilikçi iş davranışı ise yeni fikirlerin ortaya atılması, bu fikirlerin benimsenmesi, uygulanması gibi süreçleri kapsamaktadır. Bu süreçte önemli olan çalışanların fikirlerini rahatlıkla ifade edebileceği bir ortamın hazırlanması, onlara bu fırsatın tanınması, bu konuda onların teşvik edilmesidir. Böylelikle yenilikçi davranışın ortaya çıkması sağlanmış olacaktır. Bu araştırmanın yapısal ve psikolojik güçlendirmenin kariyer tatmini ile yenilikçi iş davranışı üzerinde önemini görmeye yönelik faydalı sonuçlar üreteceği düşünülmektedir.

Bu çalışma yapısal ve psikolojik güçlendirmenin kariyer tatmini ve yenilikçi iş davranışı üzerindeki ilişki ve etkilerini tespit etmek amacıyla tasarlanmıştır. Araştırma hipotezlerini test etmek amacıyla Türkiye örnekleminde, bazı üretim işletmelerinde tam zamanlı olarak görev yapan beyaz yakalı çalışanlardan anket yöntemi kullanılarak veriler toplanmıştır. Korelasyon analizi sonucunda değişkenler arasında pozitif ve anlamlı ilişkiler olduğu tespit edilmiştir. Regresyon analizi sonucunda, yapısal ve psikolojik güçlendirmenin kariyer tatmini ile yenilikçi iş davranışını pozitif yönde etkilediği tespit edilmiştir. Bu etkilerin belirlenmesinden sonra yapısal güçlendirmenin kariyer tatmini ve yenilikçi iş davranışı üzerindeki etkisinde psikolojik güçlendirmenin aracılık rolü üstlenip üstlenmediğine yönelik birinci model analiz edilmiştir. Ardından yapısal ve psikolojik güçlendirmenin yenilikçi iş davranışı üzerindeki etkisinde kariyer tatminin aracılık rolü üstlenip üstlenmediğine yönelik ikinci model analiz edilmiştir. Araştırmanın hem uygulayıcılara hem de çalışanlara katkı sağlayacağı düşünülmektedir.

\section{Kuramsal Çerçeve}

\subsection{Güçlendirme}

Güçlendirme, çalışanların yeri geldiğinde gerekli kararları nasıl alacakları ve işlerinde veya örgüt ortamında karşılaşacakları güçlüklere karşı nasıl tepki verecekleri konusunda tecrübe kazanmalarını sağlayan örgütsel davranış araştırmalarının önemli bir konusudur (Laschinger vd. 2001: 261). Literatür incelendiğinde, güçlendirmenin tek bir boyut ile tanımlanmasının zor olduğu ve güçlendirmenin iki farklı açıdan ele alındığı görülmektedir. Birincisi, yönetici faaliyet uygulamalarının asta devredilmesi yani asta güç, denetim ve yetki veren uygulamaları nitelendirmektedir. Bu güçlendirme, katılımın bir türü olarak ifade edilmektedir. Burada güç, daha az güce sahip olan astlara aktarılmaktadır. Bu güçlendirme türü "ilişkisel” yaklaşım olarak ifade edilmektedir. Bir diğer güçlendirme, çalışanın kendisini güçlendirilmiş hissedip hissetmemesini ifade eden psikolojik güçlendirmedir. Bu güçlendirme "bilişsel" veya "güdüsel" yaklaşım olarak literatürde yer almaktadır. Burada gücün devredilmesinden ziyade stres, açık iletişim, kaygı düzeyini azaltacak, duygusal desteği, bağlılığı ve katılımı arttırarak ilham verici amaçlar ortaya koymak gibi soyut unsurlar ön plana çıkmaktadır. Bilişsel yaklaşım, çalışanın işi ve iş çevresi üzerinde denetim ve seçme imkânı olduğunun farkında olması ve bu şekilde içsel duygusunu arttırmasını hedeflemektedir (Sağlam Arı ve Ergeneli, 2003: 133-134). Bu bölümde ilişkisel yaklaşım 
olarak ifade edilen yapısal güçlendirme ve bilişsel yaklaşım olarak ifade edilen psikolojik güçlendirme kavramları üzerinde durulacaktır.

\subsubsection{Yapısal Güçlendirme}

Yapısal güçlendirme kavramı, Kanter (1993) tarafından geliştirilmiştir. Kanter (1993: 166) güçlendirmeyi, "işleri yapmak için kaynakları seferber etme, harekete geçirme yeteneği" ve "bir bireyin ulaşmak istediği amaçları için ihtiyaç duyduğu kaynakları kullanabilmesi ve bağımsız bir şekilde karar alabilmesi" olarak tanımlamaktadır. Güçlü birey, yapacağı iş için araçlara erişimi olan bireydir.

Kanter (1993: 172) örgütsel ortamlarda yapılan işlerde başarının elde edilebilmesi amacıyla, öncelikle çalışanların başarılı olmalarına fırsat tanıyacak bir yapının olması gerektiğini vurgulamış, bunu "fırsat yapısı ve güç yapısı" olarak değerlendirmiştir. Kanter'e göre (1993) yapısal güçlendirme, çalışma ortamında bilgi edinme, kaynakların paylaşımı, destek, öğrenme ve büyüme fırsatlarına erişebilmeyi öneren uygulamalardan meydana gelmektedir (s.168). Yönetimin görevi, iş etkinliği için bu koşulları veya etkenleri çalışanlarına yaratmaktır. Zira çalışanlar bu etkenlere erişim sağlandığı zaman güçlendirilmiş olur veya kendini güçlendirilmiş hisseder (Orgambídez-Ramos ve Borrego-Alés, 2014: 29).

Kanter'in (1993) güçlendirme ile açıkladığı diğer kavramlar "biçimsel ve biçimsel olmayan güç"tür. Biçimsel güç, "esneklik, uyarlanabilirlik, isteğe/takdire bağlı karar verme ile ilişkili yaratıcılık, görünürlük, kurumsal amaç ve hedeflerde merkeziyetçilik" gibi belirli özelliklerden oluşmaktadır. Biçimsel olmayan güç, çalışanın örgütsel ortamda, amirleri, çalışma arkadaşları/eşitleri ve örgütte yer alan öteki fonksiyonel gruplarla sağladığı pozitif ilişkilerden ve sosyal bağlantılarından kaynaklanan gücü açıklamaktadır (Kanter, 1993: 174; Sürgevil, vd. 2013: 5374; Orgambídez-Ramos ve Borrego-Alés, 2014: 29). Sonuç olarak Kanter'e göre (1993) yapısal güçlendirme "fırsatlar, kaynaklar, destek, bilgi, biçimsel ve biçimsel olmayan güç", olmak üzere altı unsurdan oluşmaktadır. Bu unsurlar aynı zamanda yapısal güçlendirmenin boyutlarını da oluşturmaktadır (Kanter, 1993; O’Brien, 2010: 6; Sürgevil, vd. 2013: 5374; Orgambídez-Ramos ve Borrego-Alés, 2014: 29; Calvo ve Garcia, 2018: 365).

Yapısal güçlendirmeye yönelik literatürde yapılmış çalışmalar incelendiğinde, Garcia-Sierra ve Fernandez-Castro (2018) hemşireler üzerinde yaptıkları araştırmada, dönüşümcü liderliğin yapısal güçlendirmeyi doğrudan ve pozitif yönde etkilediği ve dönüşümcü liderliğin çalışan katılımı üzerindeki etkisinde aracılık rolü üstlendiğini tespit etmişlerdir. Gümüşlüoğlu ve Karakitapoğlu-Aygün (2010) Ar-Ge çalışanları üzerinde yaptıkları araştırma sonucunda, bilgi çalışanlarının güçlendirme algılarının örgüte, lidere ve işe bağlılık üzerinde olumlu ilişkiler gösterdiğini tespit etmişlerdir. Kerse ve Karabey (2014) banka çalışanları üzerinde yaptıkları araştırma sonucuna göre yapısal ve psikolojik güçlendirmenin yaratıcılığı pozitif yönde etkilediğini tespit etmişlerdir. Calvo ve Garcia (2018) orta düzey yöneticiler üzerinde yaptıkları araştırmada, yapısal güçlendirmenin tükenmişliği negatif yönde etkilediğini ve yapısal güçlendirmenin psikolojik güçlendirme yoluyla tükenmişlik üzerindeki dolaylı etkisini tespit etmişlerdir.

\subsubsection{Psikolojik Güçlendirme}

Psikolojik güçlendirme, örgüt ortamlarında çalışan bireylerin kendilerini güçlendirilmiş olarak algılayıp algılamadıklarını açıklamaktadır (Thomas ve Velthouse, 1990). Güçlendirmenin psikolojik boyutunu ifade etmektedir ve çoğu zaman yönetimsel faaliyetlere ve uygulamalara tam 
olarak bağımlı değildir. Bu güçlendirme türü daha çok çalışanların yönetimsel faaliyetleri ve uygulamaları hissedip hissetmedikleri yönündeki algılamaları ve onlara karşı geliştirdikleri tutumlarla veya davranışlarla ilişkilidir (Polatcı ve Özçalık, 2013: 20).

Yöneticilerin çalışanlara yönelik davranışları ile çalışanların bu davranışları nasıl algıladıkları birbirinden farklı olabilmektedir. Bu nedenden dolayı güçlendirme kavramı, yöneticilerin çalışanları güçlendirmek için gerçekleştirdikleri faaliyet ve uygulamaların çalışanlarca nasıl algılandığı şeklinde bilişsel bir düzeyde ele alınmıştır. Nitekim bilişsel düzeyde gerçekleşen psikolojik güçlendirme, koşulların çalışanlar tarafından algılanma ve yorumlanma durumu olarak tanımlanmaktadır. Bu güçlendirme, bireylerin çalışma ortamları ve şartlarına dair algıları tarafından şekillenerek, içsel güdülenmelerini etkiler (Erbay ve Turgut, 2015: 267).

Conger ve Kanungo (1988) tarafından ortaya konmuş olan bu yaklaşım, öz-yeterlilik kavramının motive edici bir yönü olarak tanımlanmıştır. Thomas ve Velthouse (1990) bu kavramı geliştirerek, kapsamının birkaç yönlü olduğunu ve tek bir kavramla ifade edilemeyeceğini savunmuştur. Spreitzer (1995) ise güçlendirmeyi daha geniş bir şekilde açıklamaya çalışmış "bireyin çalışma veya iş rolüne yönelik içsel görev motivasyonunu yansıtan dört biliş kümesinden" meydana geldiğini ifade etmiştir. Bu dört biliş kümesi "anlam, yetkinlik, özerklik ve etki" olmak üzere dört boyuttan oluşmaktadır (Spreitzer, 1995: 1443). Spreitzer (1995) tarafından tanımlanmış psikolojik güçlendirme boyutlarının açıklamaları şu şekildedir (Thomas ve Velthouse, 1990; Spreitzer, 1995; Laschinger, vd. 2001; O’Brien, 2010; Polatcı ve Özçalık, 2013):

Anlam: Örgüt ortamında yapmış olduğu işin gerektirdiği görev, sorumluluk ve rol ile çalışanın kendi değerleri, inançları, amaçları, tutum ve davranışları arasındaki uyumu ifade etmektedir. Bir başka ifadeyle çalışanların yaptıkları işin amaç veya niyeti ile kendi idealleri veya standartlarının değerlendirildiği bir boyuttur.

Yeterlilik: Yetkinlik veya öz yeterlilik, çalışanın işini en iyi şekilde yapabileceğine ilişkin kendi beceri ve yeteneğine olan inancıdır. Bir başka ifadeyle çalışanın hem işini hem de örgüt ortamını şekillendirmek istemesi ve bunu yapabilecek gücü kendinde hissetmesidir.

Özerklik: Yeterlilik boyutu, davranış ile ilgili yeterliliği ifade ederken; özerklik boyutu bireyin işi ile ilgili faaliyeti başlatma, sürdürme ve düzeltme ile ilgili konularda inisiyatif kullanabilmesidir. İşlerin nasıl yapılacağı konusunda karar verme özgürlüğüne ve yapılan işler üzerinde denetleme yetkisine sahip olma durumunu ifade etmektedir. Birey çalışma yöntemleri, çalışma hızı, gösterilecek çaba gibi konularda kararları kendisi alır.

Etki: İ̧̧görenin örgüt içerisindeki (stratejik, idari ve işletme) sonuçları etkileyebilmesi ve yaptığı işle o örgüte bir fark, yetenek ve değer kattığına inanmasıdır. Etki, öğrenilmiş çaresizliğin tersidir. Ayrıca kontrol odağından farklıdır. Şöyle ki etki iş bağlamında etkilenmek iken, içsel kontrol odağı değişen durumlar içerisinde küresel bir kişilik özelliğidir.

Bu dört boyut bir araya gelerek bu tarz oluşturmaktadır. Şunu ifade etmek gerekir ki, bu dört boyuttun herhangi birisinin gerçekleşmemesi psikolojik güçlendirilme duygusunu tümüyle ortadan kaldırmamaktadır, sadece duygunun hissedilme derecesinin azalmasına sebep olmaktadır denilebilir (Spreitzer, 1995, Polatcı ve Özçalık, 2013: 21).

Psikolojik güçlendirme ve yapısal güçlendirme arasındaki farkta incelenmiştir. Yapısal güçlendirme, yaptırıma bağlı gücün ve sorumluluğun dağılımını temel alarak işin yapılanma süreciyle ilgilenirken; psikolojik güçlenme, çalışanın bu sürece yönelik algısı ve bilişsel işleyişleriyle ilgilenir. Bir diğer ifade ile yapısal güçlendirme, güçlendirme koşullarının örgüt içindeki çalışma ortamındaki varlığı ya da yokluğudur; psikolojik güçlenme ise çalışanın bu koşulları psikolojik olarak 
anlamlandırma ve yorumlama şeklini ve bu örgütsel koşullara verdiği tepkiyi içerir. Bu açıdan yapısal güçlendirme aslında, psikolojik güçlenmenin en yakın öncelidir (Erbay ve Turgut, 2015: 267).

Psikolojik güçlendirmeye yönelik literatürde yapılmış çalışmalar incelendiğinde, Sağlam Arı ve Ergeneli'nin (2003) kamu ve özel sektör banka yöneticileri üzerinde yaptıkları araştırmada, psikolojik güçlendirme algısı ile örgütsel bağlılık arasında anlamlı ve pozitif yönde bir ilişki tespit etmişlerdir. Çalışkan (2011) kamu sağlık sektöründe yaptığı araştırmada, işyeri arkadaşlıkları ve örgütsel iletişimin çalışanların psikolojik güçlendirilme algıları üzerindeki etkisini tespit etmiştir. Toplu ve Akça (2013) belediye çalışanları üzerinde yaptıkları araştırmada, öğrenen organizasyona ilişkin özelliklerin, psikolojik güçlendirme üzerinde etkisi olduğu sonucuna ulaşılmışlar ve bu durumda öğrenen organizasyon haline gelmiş bir işletmede psikolojik güçlendirmenin de yüksek olacağını ifade etmişlerdir. Erdem ve arkadaşları (2016) kamuda eğitim sektörü çalışanları üzerinde yaptıkları araştırmada, psikolojik güçlendirme boyutlarının (anlam, yetkinlik, etki, özerklik) iş performansını pozitif yönde ve anlamlı olarak etkilediği tespit etmişlerdir. Ayrıca örgütsel bağlılığın, psikolojik güçlendirmenin alt boyutlarıyla iş performansı arasındaki ilişkide aracılık rolü oynadığını belirlemişlerdir.

\subsection{Kariyer Tatmini}

Bireyler, yaşamlarının büyük bir bölümünü örgüt ortamlarından çalışarak geçirdiğinden, iş bu bireyler için yaşamsal bir olgu haline gelmektedir. Dolayısıyla çalışan her bireyin, geleceğini planlayabilmek için, işindeki veya mesleğindeki ilerleme olanaklarını yani kariyer kavramını ve kariyer fırsatlarını iyi bilmesi ve anlaması gerekmektedir. Bu bilinç, bireyin kim olduğunu ve nerede durduğunu anlamasına yardımcı olur. Bunun yanı sıra bireye gerekirse ilerleme ve gerekirse geri çekilme gücü verir. Özellikle destekleyici ve anlayışlı yöneticiler, çalışanların işlerinde veya mesleklerinden ilerlemesinin önemini anlayan ve onların mutlu, verimli, yenilikçi oldukları sürece örgütte kalmalarını sağlayan yöneticilerdir (Barutçugil, 2004: 319). Kariyer kavramı meslekte yükselme, belirli bir statü elde etme ve tercih edilen bir meslek sahibi olma şeklinde algllanmaktadır. Aynı zamanda bireyin yaşamı boyunca elde ettiği işi ile ilgili deneyimleridir (Sabuncuoğlu, 2012: 168).

Kariyer tatmini, çalışanların örgütlerinde kariyerlerine yönelik amaç ve beklentilerine ulaşma derecesine ilişkin algılarını ifade etmektedir (Sakal ve Yıldız, 2015: 6613). Kariyer tatmini, bireylerin kendi kariyerleriyle ilgili kendi kendine özgü değerlendirmeleri olarak genellikle öznel kariyer başarısının merkezi bir göstergesi olarak görülmektedir. Bireyin, kariyerle ilgili farklı hedeflere (örneğin, gelir, başarı, gelişim) ve kariyerle ilgili başarılara ulaşma yolundaki ilerlemesinin değerlendirilmesidir (Spurk vd. 2011: 315).

Kariyer tatmini iki boyutta açıklanmaktadır. Birincisini bireylerin kariyer başarıları ve kariyerlerinden elde ettikleri tatmin oluşturmaktadır. İkincisini çalıştıkları örgütte ulaşmak istedikleri kariyer ilerlemelerine yönelik çalışanların algıladıkları güven duygusu ve umut oluşturmaktadır (Sakal ve Yıldız, 2015: 6613). Greenhaus ve diğerleri (1990: 86), bireylerin örgüt ortamlarında kariyer tatmininde beş temel konunun önemini vurgulamıştır. Bu faktörler aynı zamanda kariyer tatmini ölçeğinin özetini oluşturmaktadır, bunlar "kariyer başarıları, tüm kariyer hedeflerine ulaşma derecesi, gelir hedeflerine ilişkin ilerleme derecesi, kendini geliştirme hedeflerine ilişkin ilerleme derecesi ile yeni beceri ve yetkinlik elde etme konusunda elde edilen ilerlemelerdir. Greenhaus ve arkadaşlarına (1990: 67) göre yöneticilerin kariyeri de, üst denetçilerin destekleyici ilişkileri ile zenginleştirilebilir. Buna göre yapısal ve psikolojik güçlendirme örgüt 
yöneticilerinin desteğini içermektedir. Bu durum elbette örgüt içerinde çalışanların kariyer durumlarını etkileyebilir. Greenhaus ve arkadaşlarının (1990: 66) kariyer tatmini için önerdikleri model aşağıda gösterilmiştir.

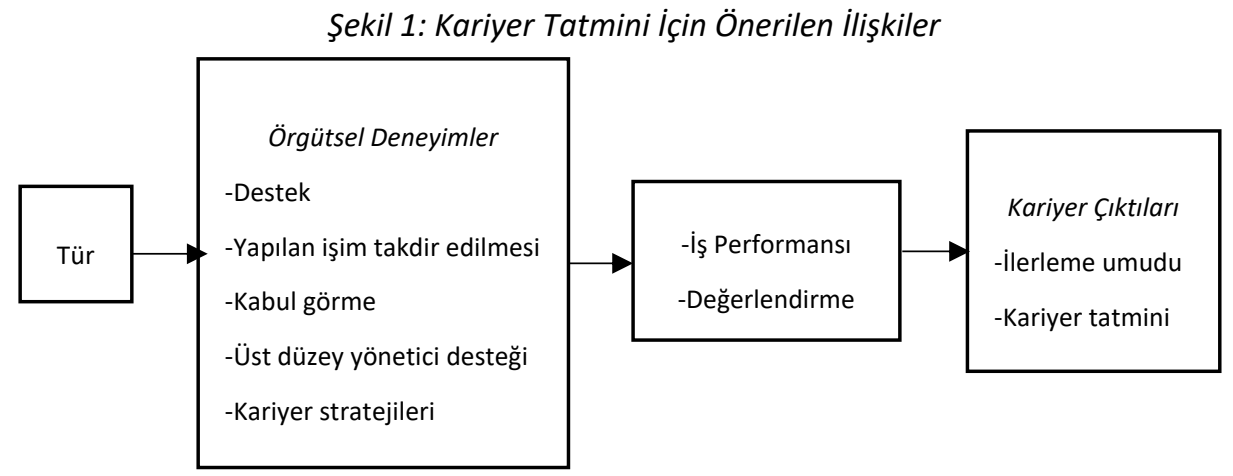

Şekilde de görüldüğü gibi kariyer tatmini için kariyer stratejileri, yöneticilerin desteği gibi konular önem arz etmektedir. Kariyer tatminine yönelik literatürde yapılmış çalışmalar incelendiğinde, iş performansı (Çavuş ve İmadoğlu, 2017), yaratıcı örgüt iklimi ve duygusal bağlılık (Gürkan ve Koçoğlu, 2014), iş-aile çatışması ve iş tatmini (Yüksel, 2005), işkoliklik (Ulukök ve Akın, 2016), iç kariyer çapaları ve dış kariyer fırsatları (Jiang vd. 2001) üzerine yapılmış çalışmaları görmek mümkündür.

\subsection{Yenilikçi İş Davranışı}

Yenilik İngilizce'de inovation ya da innovation olarak ifade edilmektedir. Yenilik kavramı, yeni fikirlerin, süreçlerin, ürünlerin veya hizmetlerin üretimi, kabulü ve uygulanmasıdır. Kabul ve uygulama bu tanımın merkezini oluşturmaktadır ve değişme ve uyum sağlama kapasitesini içerir (Hjalager, 2010: 2). 1880'lerin sonlarından bu yana, yenilik kavramının kullanılmasının olağandışı bir anlam ifade ettiği yönünde haberler olmasına rağmen, ilk yenilik öncüllerinin hiçbiri Schumpeter kadar etkili olmamıştır (Sledzik, 2013: 90). Yenilik kavramında öncü olan Schumpeter (1939) özellikle buluş ve yenilik kavramları arasındaki farka dikkat çekmeye çalışmıştır. Buluş ya da icat kelimesi, bilimsel ve teknolojik araştırmalarla yakından ilişkili ve bağlantılıdır aynı zamanda gerçek olan atılımları tanımlamak için kullanılmaktadır. Buluş, belirli bir endüstriyel kullanıma yönelik değildir. Diğer taraftan yenilik, buluşların daha da gelişmesi ya da onları faydalı ürün haline getirmek için parlak fikirleri ifade etmektedir. (Aktaran: Hjalager, 2002: 465). Yenilik, fikirlerin uygulanması ve fikirlerin kullanılması için benimsenmesi ve üretimde kullanılması ile ilgilidir (Scoot ve Bruce, 1994: 581). Yenilik beş kategorinin birinin ya da birkaçının bir araya getirilmesi ile gerçekleşmektedir. Bunlar: "ürün yenilikleri, süreç yenilikleri, yönetim yenilikleri, lojistik yenilikleri, kurumsal yenilikler" şeklinde ifade edilmektedir (Hjalager, 2002: 465-466).

Yenilik kavramı örgüt ortamlarında, çalışanlardan beklenen bir davranış biçimi şeklinde ifade edilebilir. Çalışanların bu konuda teşvik edilmesi örgütün en temel görevlerinden birisi haline gelmiştir. Ayrıca çalışanın fikirlerini rahatlıkla ifade edebileceği bir ortamın hazırlanması, çalışanın işini sevmesi, örgütüne bağlanması gibi örgüt için değerli konular yenilikçi davranışın ortaya çıkmasında bir etken olabilir.

Yenilikçi davranış, çalışanın bilinçli olarak prosedür, ürün ve süreçlerle ilgili yeni fikirleri benimsemesi ve bunları kendi işine, çalıştığı departmanına veya işletmenin tamamına uygulaması olarak tanımlanmaktadır. Çalışanlar tarafından yapılan; yeni teknolojileri bulma veya keşfetme, hedeflere ulaşmayı sağlayacak yeni yollar düşünme ve teklif etme, yeni çalışma yöntemleri ve 
yeni fikirleri uygulamak için gerekli olan yeni kaynakları araştırma ve garanti altına alma gibi davranışlar, yenilikçi davranış içinde değerlendirilmektedir (Çalışkan, 2013: 95). Bir diğer ifade ile yenilikçi iş davranışı, örgüt yararı için, fikirlerin bilinçli bir şekilde oluşturulması ve uygulanmasıdır (Turgut ve Beğenirbaş, 2013: 108). Yenilikçi iş davranışı fikirlerin düşünülmesi, ortaya çıkarılması ve uygulanması süreçlerini kapsamaktadır. Yenilikçi davranış sonunda "yenilik" olarak nitelendirilen çıktıların elde edilmesi beklenir. Bu süreçte fikrin keşfedilmesi-açıklanması, fikrin üretilmesi-ifade edilmesi, fikrin desteklenmesi-kabul edilmesi ve fikrin uygulanması-gün yüzüne çıkması en temel aşamalardır (Örnek ve Ayas, 2015: 96-98). Yenilikçi iş davranışına yönelik literatürde yapılmış çalışmalar incelendiğinde, proaktif kişilik, içsel ve dışsal kontrol odağı (Kale, 2019), lider-üye etkileşimi (Bilal vd. 2019; Schuh vd. 2018), anlamlı iş (Cai vd. 2018), psikolojik sahiplenme (Derin, 2018), psikolojik sermaye (Örücü ve Çınar, 2019), psikolojik güçlendirme (Aydın, 2016) üzerine yapıımış çalışmaları görmek mümkündür.

\section{Araştırma Değişkenleri Arasındaki ilişskiler}

Tolay ve arkadaşlarının (2012) araştırma görevlileri üzerinde yaptıkları çalışmada yapısal güçlendirmenin psikolojik güçlendirmeye doğrudan, pozitif ve güçlü şekilde etkilediği sonucuna ulaşmışlardır. Dan ve arkadaşlarının (2018) Çin'de hemşireler üzerinde yaptıkları çalışmada, yapısal güçlendirme, kariyer tatmini ve yenilikçi iş davranışı arasında pozitif bir ilişki olduğunu ve yapısal güçlendirmenin yenilikçi iş davranışını pozitif olarak etkilediğini tespit etmişlerdir. Knol ve van Linge'nin (2009) Hollanda'da hemşireler üzerinde yaptıkları çalışmada yapısal ve psikolojik güçlendirmenin yenilikçi iş davranışını pozitif ve anlamlı bir şekilde etkilediğini ve psikolojik güçlendirmenin yapısal güçlendirme ve yenilikçi iş davranışı arasında aracılık etkisi olduğunu tespit etmişlerdir. Haiyan ve arkadaşlarının (2016) Çin'de konaklama işletmelerinde $Y$ kuşağı üzerinde yaptıkları çalışmada, psikolojik güçlendirmenin kariyer tatmini ve kariyer yetkinlikleri ile pozitif ilişkili olduğu sonucuna ulaşmışlardır. Prabowo ve arkadaşları (2018) özel ve kamu sektör çalışanları üzerinde yaptıkları araştırmada, dönüşümcü liderliğin yenilikçi iş davranışını psikolojik güçlendirme yolu ile etkilediği sonucuna ulaşmışlardır. Aydın (2016) kamu ve özel sektörde çalışanlar üzerinde yaptığı çalışmada, yaratıcı iklim, psikolojik güçlendirme, yenilikçi iş davranışı değişkenleri arasında pozitif ve anlamlı bir ilişkinin var olduğunu ve psikolojik güçlendirme algısının yaratıcı iklim ve yenilikçi iş davranışı arasında aracı rol oynadığı sonucuna ulaşmıştır. Yapılan araştırmalardan destek alınarak kurulan hipotezler şu şekildedir:

H1: Yapısal güçlendirme psikolojik güçlendirme üzerinde anlamlı ve pozitif yönde etkiye sahiptir.

H2: Psikolojik güçlendirme kariyer tatmini üzerinde anlamlı ve pozitif yönde etkiye sahiptir.

H3: Psikolojik güçlendirme yenilikçi iş davranışları üzerinde anlamlı ve pozitif yönde etkiye sahiptir.

H4: Yapısal güçlendirme kariyer tatmini üzerinde anlamlı ve pozitif yönde etkiye sahiptir.

H5: Yapısal güçlendirme yenilikçi iş davranışları üzerinde anlamlı ve pozitif yönde etkiye sahiptir.

H6: Yapısal güçlendirmenin kariyer tatmini üzerindeki etkisinde psikolojik güçlendirme aracılık rolü üstlenmektedir.

H7: Yapısal güçlendirmenin yenilikçi iş davranışı üzerindeki etkisinde psikolojik güçlendirme aracılık rolü üstlenmektedir. 
Bu çalışmada kariyer tatmininin yapısal ve psikolojik güçlendirme ile yenilikçi iş davranışı arasında aracılık rolü üstlenip üstlenmediği de analiz edilmiştir. Bu model için kurulan hipotezler birinci model için kurulan hipotezlere devam niteliğindedir. Bu modelin hipotezleri şu şekildedir:

H8: Kariyer tatmini yenilikçi iş davranışı üzerinde anlamlı ve pozitif yönde etkiye sahiptir.

H9: Yapısal güçlendirmenin yenilikçi iş davranışı üzerindeki etkisinde kariyer tatmini aracılık rolü üstlenmektedir.

H10: Psikolojik güçlendirmenin yenilikçi iş davranışı üzerindeki etkisinde kariyer tatmini aracılık rolü üstlenmektedir.

Yapılan araştırmalardan yola çıkılarak oluşturulan araştırma modelleri aşağıda sunulmuştur. Model 1. Psikolojik güçlendirmenin yapısal güçlendirme ile kariyer tatmini ve yenilikçi iş davranışı arasında aracı rolü

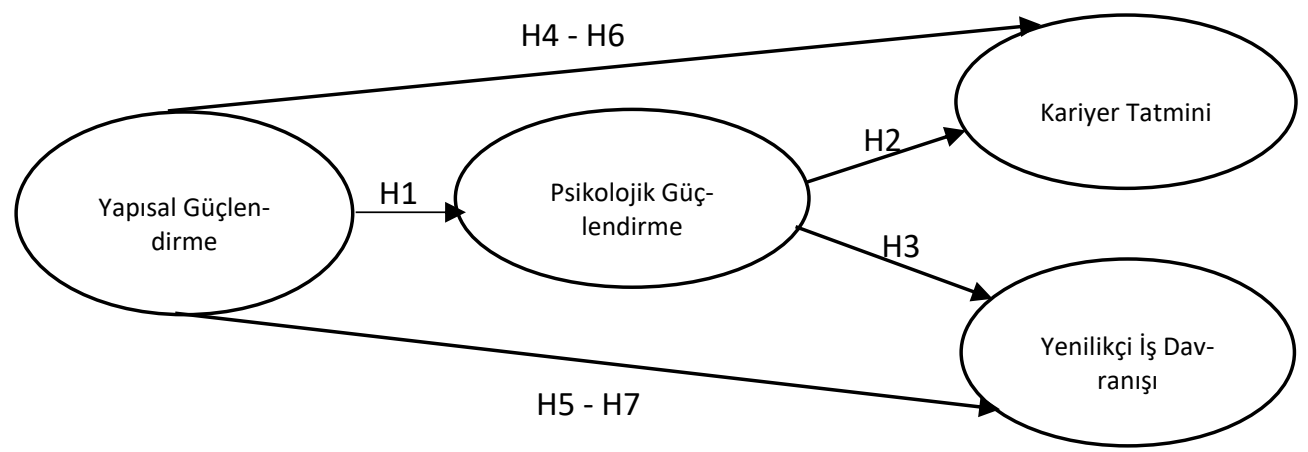

Model 2. Kariyer tatminin yapısal ve psikolojik güçlendirme ile yenilikçi iş davranışı arasındaki aracı rolü

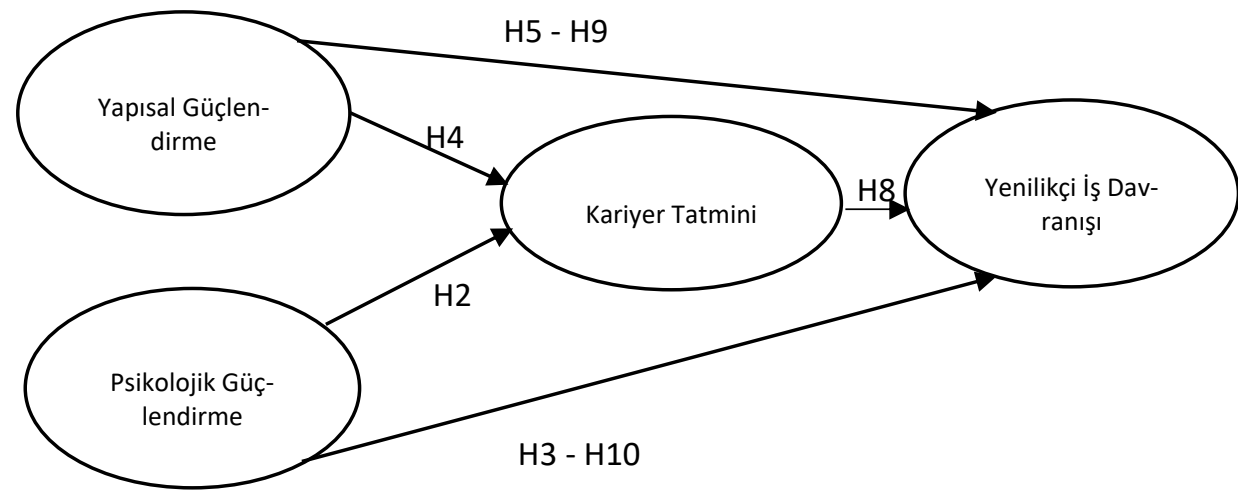

\section{Araştırmanın Yöntemi}

Araştırmada öncelikle yapısal ve psikolojik güçlendirmenin kariyer tatmini ile yenilikçi iş davranışı üzerindeki etkisi belirlenecektir. Ardından Model 1 (yapısal güçlendirme ile kariyer tatmini ve yenilikçi iş davranışı arasında psikolojik güçlendirmenin aracılık etkisi) ile Model 2 (ya- 
pısal ve psikolojik güçlendirme ile yenilikçi iş davranışı kariyer tatminin aracılık etkisi) incelenecektir. illk aşamada örneklem ve veri toplama araçlarına yönelik bilgiler verilmiştir. Veri toplama araçlarının DFA analizleri açıklandıktan sonra, araştırmanın modellerine yönelik analizlere geçilmiştir. Modellerde yer alan değişkenler arasındaki korelasyon katsayıları tespit edildikten sonra, regresyon analizi aracılığıyla kurulan hipotezler test edilmiştir. Analizler sonucunda elde edilen bulgular sonuç bölümünde yorumlanmıştır.

\subsection{Araştırmanın Örneklemi ve Veri Toplama Araçları}

Araştırmanın örneklemini, Türkiye'de bazı üretim işletmelerinde tam zamanlı olarak görev yapan beyaz yakalı çalışanlar oluşturmaktadır. Örnekleme metodu olarak kolayda örnekleme yöntemi kullanıımıştır. Gönüllülük esasına dayalı olarak dağıtılan 250 anket formlarından 181 anket geri dönmüş, hatalı ve eksik doldurulmuş anket formları çıkarıldıktan sonra 144 anket analize tabi tutulmuştur. Örneklemin \%79.6 (117) erkek, yaş ortalaması 36.10 ve yaşlar 21-60 aralığındadır. Katılımcıların \% 64,6 (95) evli, \%34,0 (50) 11-15 yıl mesleki deneyime sahip olduğu belirlenmiştir.

Araştırmada kullanılan anket formu beş bölümden oluşmaktadır. İlk 4 bölümde araştırma değişkenleri ile ilgili ölçekler, son bölümde ise katılımcıların demografik özellikleri hakkında sorular bulunmaktadır. Tüm ölçekler için 5'li likert tipi derecelendirme kullanılmıştır.

Yapısal Güçlendirme Ölçeği: Yapısal güçlendirme düzeyini belirlemek üzere Laschinger ve arkadaşları (2001) tarafından geliştirilen olan 18 ifadeli ölçek kullanılmıştır. Güvenilirlik analizi sonucunda ölçeğin Cronbach alfa katsayısı .63 olarak bulunmuştur. Ölçekte, "Tüm bilgi ve becerilerimi işimde kullanabilmekteyim" ve "Işsimde iyi yaptığım şeyler kurumumca desteklenir" şeklinde sorular yer almaktadır. Yapısal güçlendirme ölçeğinin geçerliliğini test etmek için doğrulayıcı faktör analizi (DFA) yapılmıştır. DFA'ya göre $(x 2=110.117(\mathrm{df}=94), x 2 / d f=1.171$, $\mathrm{RMSEA}=0.035, \mathrm{GFI}=0.920, \mathrm{CFI}=0.983, \mathrm{NFI}=0.901$ ) uyum iyiliği değerlerinin belirlenen referans aralığında olduğu görülmektedir (İyi uyum referans aralığı : $x 2 / d f \leq 5, R M S E A \leq 0.08, G F I \geq 0.90$, CFI $\geq 0.90, \mathrm{NFI} \geq 0.90$, Çokluk, vd., 2014: 271-272).

Psikolojik Güçlendirme Ölçeği: Psikolojik güçlendirme düzeyini belirlemek üzere Spreitzer (1995) tarafından geliştirilen 12 ifadeli ölçek kullanılmıştır. Güvenilirlik analizi sonucunda ölçeğin Cronbach alfa katsayısı .81 olarak tespit edilmiştir. Ölçekte, "İşimi bağımsız olarak ve özgürce yapabilme imkânına sahibim" ve "Yaptığım iş benim için önemlidir" şeklinde sorular yer almaktadır. Psikolojik güçlendirme ölçeğinin geçerliliğini test etmek için doğrulayıcı faktör analizi (DFA) yapılmıştır. DFA'ya göre $(x 2=56.334(\mathrm{df}=27), \mathrm{x} 2 / \mathrm{df}=1.716, \mathrm{RMSEA}=0.071, \mathrm{GFI}=0.948$, $\mathrm{CFI}=0.970, \mathrm{NFI}=0.934)$ uyum iyiliği değerlerinin belirlenen referans aralığında olduğu görülmektedir.

Kariyer Tatmini Ölçeği: Kariyer tatmin düzeyini belirlemek üzere, Greenhaus ve arkadaşları (1990) tarafından geliştirilen 5 ifadeli ölçek kullanılmıştır. Güvenilirlik analizi sonucunda ölçeğin Cronbach alfa katsayısı .74 olarak tespit edilmiştir. Ölçekte, "Kariyerimde ulaştığım başarım beni mutlu ediyor" ve "Terfi hedeflerime yönelik gösterdiğim ilerleme beni tatmin ediyor" gibi sorular yer almaktadır. Kariyer tatmini ölçeğinin geçerliliğini test etmek için doğrulayıcı faktör analizi (DFA) yapılmıştır. DFA'ya göre $(x 2=3.743(\mathrm{df}=3), \mathrm{x} 2 / \mathrm{df}=1.248, \mathrm{RMSEA}=0.042, \mathrm{GFI}=0.990$, $\mathrm{CFI}=0.996, \mathrm{NFI}=0.982$ ) uyum iyiliği değerlerinin belirlenen referans aralığında olduğu görülmektedir.

Yenilikçi İ̧̧ Davranışı Ölçeği: Yenilikçi iş davranışı düzeyini belirlemek üzere Scott ve Bruce (1994) tarafından kullanılan 6 ifadeli ölçek kullanılmıştır. Güvenilirlik analizi sonucunda ölçeğin 
Cronbach alfa katsayısı .70 olarak tespit edilmiştir. Ölçekte, "Yeni teknolojiler, süreçler, teknikler araştırım ve fikirler üretirim" ve "Yaratıcı fikirler üretirim" gibi sorular yer almaktadır. Yenilikçi iş davranışı ölçeğinin geçerliliğini test etmek için doğrulayıcı faktör analizi (DFA) yapılmıştır. DFA'ya göre ( $x 2=5.514(\mathrm{df}=4), \mathrm{x} 2 / \mathrm{df}=1.378, \mathrm{RMSEA}=0.051, \mathrm{GFI}=0.988, \mathrm{CFI}=0.995, \mathrm{NFI}=0.982$ ) uyum iyiliği değerlerinin belirlenen referans aralığında olduğu görülmektedir.

\subsection{Bulgular}

Katılımcılardan elde edilen veriler SPSS programında analiz edilmiştir. Araştırmada öncelikle değişkenlerin istatistiksel değerlerine bakılmıştır. Analiz sonucunda elde edilen istatistiksel değerler (ortalama, standart sapma) ve korelasyon değerleri Tablo 1'de görülmektedir.

Tablo 1. Değişkenlerin İstatistiksel Değerleri ve Korelasyon Katsayıları

\begin{tabular}{llllll}
\hline & Ort. & SS. & $\mathbf{1}$ & $\mathbf{2}$ & $\mathbf{3}$ \\
\hline 1.Yapısal Gü̈çlendirme & 3.65 & .36 & - & & \\
\hline 2.Psikolojik Güçlendirme & 3.88 & .48 & $.590^{* *}$ & - & \\
\hline 3.Kariyer Tatmini & 3.77 & .57 & $.403^{* *}$ & $.463^{* *}$ & - \\
\hline 4.Yenilikçi İ̧̧ Davranışı & 4.11 & .46 & $.469^{* *}$ & $.498^{* *}$ & $.271^{* *}$ \\
\hline
\end{tabular}

${ }^{*} p<.05,{ }^{* *} p<.01$

Araştırmanın değişkenleri olan yapısal güçlendirme, psikolojik güçlendirme, kariyer tatmini ve yenilikçi iş davranışının birbirleri ile ilişkilerinin anlamlı ve pozitif olduğu tespit edilmiştir. Model 1 olan, yapısal güçlendirme ile kariyer tatmini ve yenilikçi iş davranışı arasında psikolojik güçlendirmenin aracılık etkisi olup olmadığını belirlemek amacıyla SPSS programında Baron ve Kenny'nin (1986) aracılık etkisi analizi yapılmıştır. Model 2 için de aynı analiz yolu izlenmiştir. Model 1'in analiz sonuçları aşağıda verilmiştir.

Model 1.1. Psikolojik Güçlendirmenin Yapısal Güçlendirme-Kariyer Tatmini Arasındaki Etkileşimdeki Aracılık Rolü

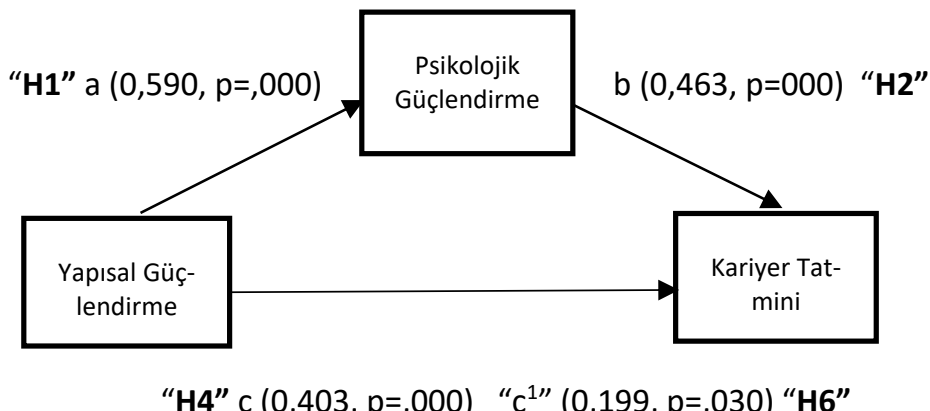

Tablo 2: Model 1.1'in Istatistiksel Sonuçları

\begin{tabular}{lccccc}
\hline & $\boldsymbol{\beta}$ & $\mathbf{F}$ & $\mathbf{R 2}$ & Düzeltilmiş R2 & Sig. \\
\hline "a" yolu, & 0,590 & 75,833 &, 348 &, 344 &, 000 \\
\hline "b" yolu & 0,463 & 38.814 &, 215 &, 209 &, 000 \\
\hline "c" yolu & 0,403 & 27.558 &, 163 &, 157 &, 000 \\
\hline "c1" yolu & 0,199 & 27.558 &, 163 &, 230 &, 000 \\
\hline
\end{tabular}

Tablo 2 incelendiğinde, Baron ve Kenny'nin (1986) üç koşulunun gerçekleştiği görülmektedir. Aracı etkinin belirlenmesi için, bağımsız ve aracı değişken modele birlikte dâhil edildiğinde "c1" yolunun etkisinin azalıp azalmadığına bakılmıştır. "c1" yolu incelendiğinde standardize 
edilmiş $\beta$ katsayısı değerinde $(0,199 ; p=0,030)$ bir azalmanın olduğu ( $F=22.327 ; R 2=, 241$; Düzeltilmiş R2=,230), ancak yapısal güçlendirmenin kariyer tatmini üzerindeki etkisinin modele psikolojik güçlendirmenin aracı değişken olarak dâhil edilmesi ile bütünüyle ortadan kalkmadığı görülmektedir. Bu nedenle psikolojik güçlendirmenin yapısal güçlendirme ve kariyer tatmini arasında kısmi aracılık rolü oynadığını söylemek mümkündür. Bu sonuca göre H6 hipotezi de kabul edilmiştir. Birinci modelin aracılık etkisinin istatistiksel olarak anlamlılığını kontrol etmek amacıyla Sobel Testi yapılmıştır. Sobel testinin hesaplanması sonucunda aracılık etkisinin istatistiksel olarak anlamlı $(z=5,386, p=0,000)$ olduğu bulunmuştur. Ayrıca analiz kapsamında bağımsız değişkenler arasında çoklu eş doğrusallık (multicollinearity) problemi olmadığı (Tolerans $>$.2; VIF < 10) tespit edilmiştir (Tolerans=.652; VIF=1.534).

Model 1.2. Psikolojik Güçlendirmenin Yapısal Güçlendirme-Yenilikçi Işs Davranışı Arasındaki Etkileşimdeki Aracılık Rolü

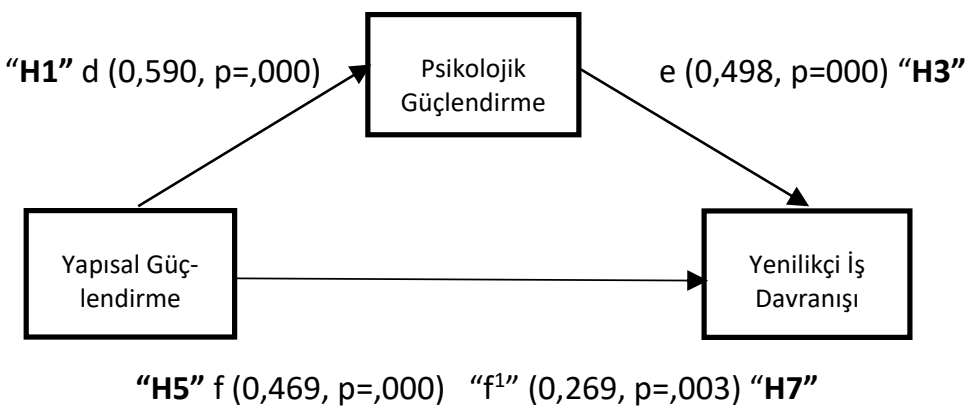

Tablo 3: Model 1.2'nin istatistiksel Sonuçları

\begin{tabular}{lccccc}
\hline & $\boldsymbol{\beta}$ & $\mathbf{F}$ & $\mathbf{R 2}$ & Düzeltilmiş R2 & Sig. \\
\hline "d" yolu & 0,590 & 75,833 &, 348 &, 344 &, 000 \\
\hline "e" yolu & 0,498 & 46.889 &, 248 &, 243 &, 000 \\
\hline "f" yolu & 0,469 & 40.104 &, 220 &, 215 &, 000 \\
\hline "f1" yolu & 0,269 & 29.555 &, 295 &, 285 &, 003 \\
\hline
\end{tabular}

Tablo 3 incelendiğinde yapısal güçlendirmenin yenilikçi iş davranışı üzerindeki etkisinin modele psikolojik güçlendirmenin aracı değişken olarak dâhil edilmesi ile bütünüyle ortadan kalkmadığı görülmektedir. Psikolojik güçlendirmenin yapısal güçlendirme ve yenilikçi iş davranışı arasında kısmi aracılık rolü oynadığını söylemek mümkündür. Bu sonuca göre $\mathbf{H 7}$ hipotezi de kabul edilmiştir (Sobel testi: $z=5,377, p=0,000$ ve Tolerans=.652; VIF=1.534).

Model 3. Birinci Modelin Nihai Hali

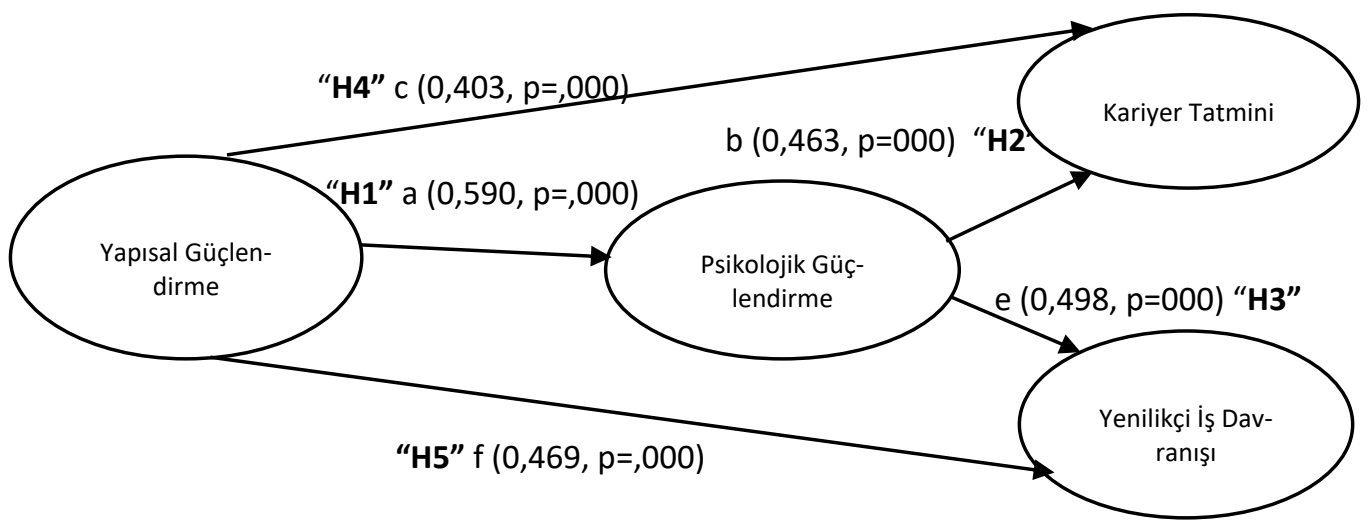


Aracılık Etkisi 1: Yapısal Güçlendirme-Psikolojik Güçlendirme-Kariyer Tatmini = " $c^{1 "}(0,199$, $\mathrm{p}=, 030)$ "H6"

Aracılık Etkisi 2: Yapısal Güçlendirme-Psikolojik Güçlendirme-Yenilikçi İş Davranışı " $f$ " $"(0,269$, $\mathrm{p}=$,003) "H7"

\section{Araştırmanın İkinci Aşaması}

Bu çalışmada iki farklı model karşılaştırmalı olarak incelenecek ve modeller arasındaki çıkan sonuçlar yine karşılaştırmalı olarak değerlendirecektir. Buna göre araştırmanın ikinci modeli aşağıda gösterilmiştir. Model 2 için yapılan analiz sonuçları aşağıda verilmiştir.

Model 2.1. Kariyer Tatminin Yapısal Güçlendirme-Yenilikçi Iş Davranışı Arasındaki Etkileşimdeki Aracılık Rolü

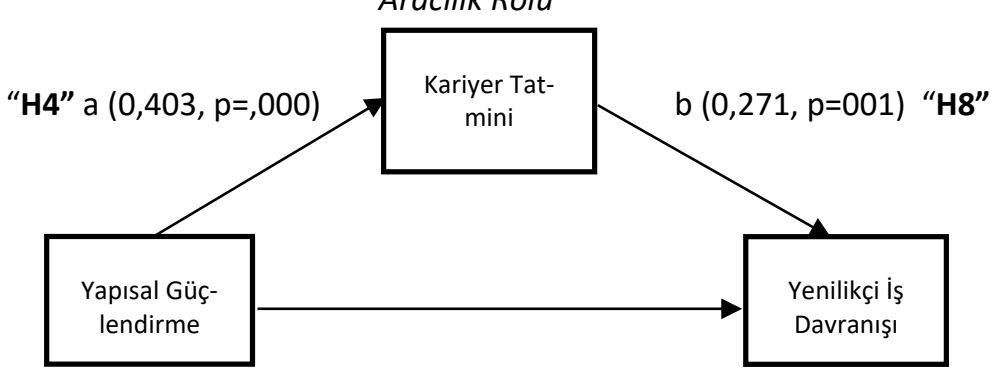

“H5” c $(0,469, p=, 000)$ “c ${ }^{1 ”}(0,430, p=, 000)$ “H9”

Tablo 4: Model 2.1'nin istatistiksel Sonuçları

\begin{tabular}{lccccc}
\hline & $\boldsymbol{\beta}$ & $\mathbf{F}$ & $\mathbf{R 2}$ & Düzeltilmiş R2 & Sig. \\
\hline "a" yolu, & 0,403 & 27,567 &, 163 &, 157 &, 000 \\
\hline "b" yolu & 0,271 & 11.291 &, 074 &, 067 &, 001 \\
\hline "c" yolu & 0,469 & 40.104 &, 220 &, 215 &, 000 \\
\hline "c1" yolu & 0,430 & 20.855 &, 228 &, 217 &, 003 \\
\hline
\end{tabular}

Tablo 4 incelendiğinde yapısal güçlendirmenin yenilikçi iş davranışı üzerindeki etkisinin modele kariyer tatmininin aracı değişken olarak dâhil edilmesi ile bütünüyle ortadan kalkmadığı görülmektedir. Kariyer tatmininin yapısal güçlendirme ve yenilikçi iş davranışı arasında kısmi aracılık rolü oynadığını söylemek mümkündür. Bu sonuca göre $\mathbf{H 9}$ hipotezi de kabul edilmiştir (Sobel testi: $\mathrm{z}=3,00, \mathrm{p}=0,002$ ve Tolerans=.837; VIF=1.194).

Model 2.2. Kariyer Tatminini Psikolojik Güçlendirme-Yenilikçi İ̧̧ Davranışı Arasındaki Etkileşimdeki Aracılık Rolü

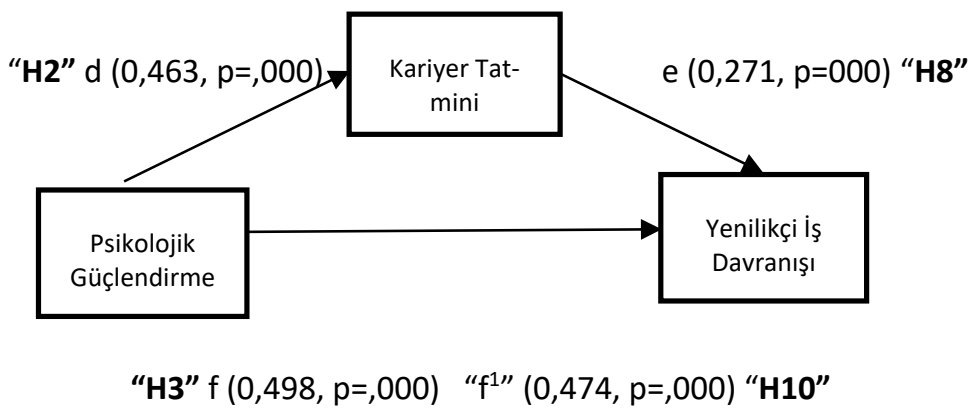


Tablo 5: Model 2.2'nin istatistiksel Sonuçları

\begin{tabular}{lccccc}
\hline & $\boldsymbol{\beta}$ & $\mathbf{F}$ & $\mathbf{R 2}$ & Düzeltilmiş R2 & Sig. \\
\hline "d" yolu & 0,463 & 38,814 &, 215 &, 209 &, 000 \\
\hline "e" yolu & 0,271 & 11.291 &, 074 &, 067 &, 001 \\
\hline "f" yolu & 0,498 & 46.889 &, 248 &, 243 &, 000 \\
\hline "f1" yolu & 0,474 & 30.542 &, 250 &, 240 &, 000 \\
\hline
\end{tabular}

Tablo 5 incelendiğinde psikolojik güçlendirmenin yenilikçi iş davranışı üzerindeki etkisinin modele kariyer tatminini aracı değişken olarak dâhil edilmesi ile bütünüyle ortadan kalkmadığı görülmektedir. Kariyer tatmininin psikolojik güçlendirme ve yenilikçi iş davranışı arasında kısmi aracılık rolü oynadığını söylemek mümkündür. Bu sonuca göre $\mathbf{H 1 0}$ hipotezi de kabul edilmiştir (Sobel testi: $z=3,235, p=0,001$ ve Tolerans=.785; VIF=1.273).

Model 4. Ikinci Modelin Nihai Hali

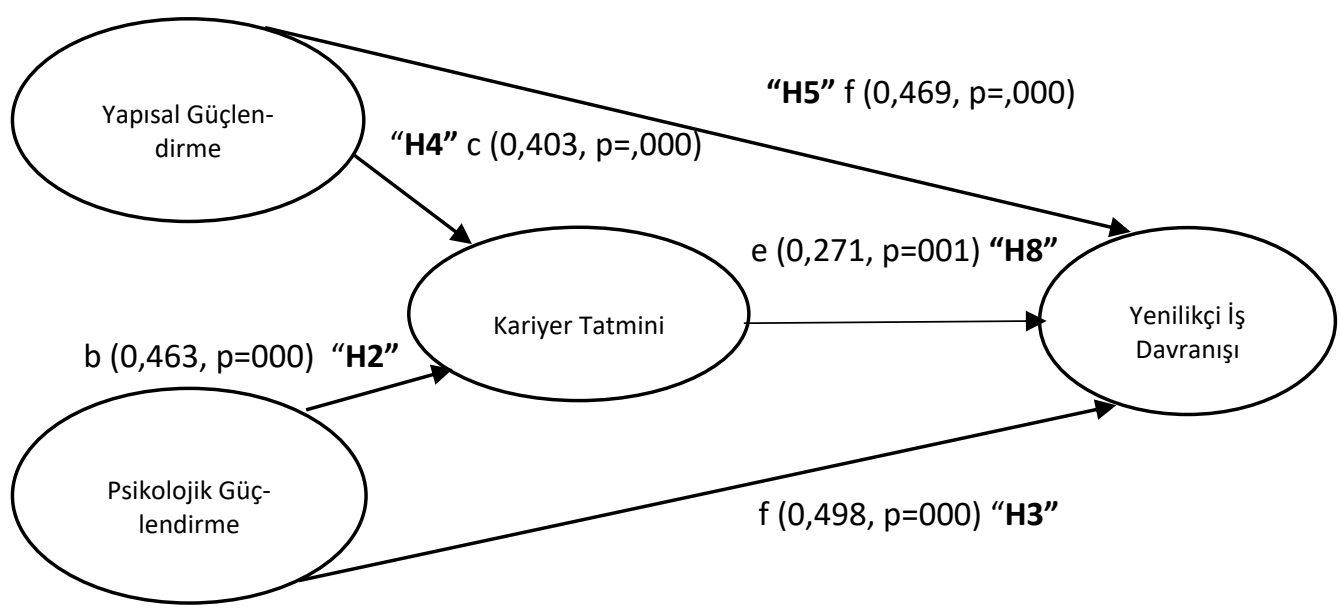

Aracılık Etkisi 3: Yapısal Güçlendirme-Kariyer Tatmini-Yenilikçi İş Davranışı = " $\mathrm{g}^{1 ”}(0,199, \mathrm{p}=, 030)$ "H9"

Aracılık Etkisi 4: Psikolojik Güçlendirme- Kariyer Tatmini-Yenilikçi İş Davranışı= " $\mathrm{e}^{1 "}(0,269$, $\mathrm{p}=, 003)$ "H10" 
Tablo 6. Araştırmada Kurulan Hipotezlerin Kabul/Ret Durumları

\begin{tabular}{|c|c|c|c|}
\hline Hipotez & Hipotez İçeriği & Kabul & Ret \\
\hline H1 & $\begin{array}{l}\text { Yapısal güçlendirme psikolojik güçlendirme üzerinde anlamlı ve pozitif yönde } \\
\text { etkiye sahiptir. }\end{array}$ & $\checkmark$ & \\
\hline $\mathrm{H} 2$ & $\begin{array}{l}\text { Psikolojik güçlendirme kariyer tatmini üzerinde anlamlı ve pozitif yönde et- } \\
\text { kiye sahiptir }\end{array}$ & $\checkmark$ & \\
\hline H3 & $\begin{array}{l}\text { Psikolojik güçlendirme yenilikçi iş davranışları üzerinde anlamlı ve pozitif } \\
\text { yönde etkiye sahiptir. }\end{array}$ & $\checkmark$ & \\
\hline H4 & $\begin{array}{l}\text { Yapısal güçlendirme kariyer tatmini üzerinde anlamlı ve pozitif yönde etkiye } \\
\text { sahiptir. }\end{array}$ & $\checkmark$ & \\
\hline H5 & $\begin{array}{l}\text { Yapısal güçlendirme yenilikçi iş davranışları üzerinde anlamlı ve pozitif yönde } \\
\text { etkiye sahiptir. }\end{array}$ & $\checkmark$ & \\
\hline H6 & $\begin{array}{l}\text { Yapısal güçlendirmenin kariyer tatmini üzerindeki etkisinde psikolojik güçlen- } \\
\text { dirme aracılık rolü üstlenmektedir. }\end{array}$ & $\checkmark$ & \\
\hline $\mathrm{H7}$ & $\begin{array}{l}\text { Yapısal güçlendirmenin yenilikçi iş davranışı üzerindeki etkisinde psikolojik } \\
\text { güçlendirme aracılık rolü üstlenmektedir. }\end{array}$ & $\checkmark$ & \\
\hline H8 & $\begin{array}{l}\text { Kariyer tatmini yenilikçi iş davranışı üzerinde anlamlı ve pozitif yönde etkiye } \\
\text { sahiptir. }\end{array}$ & $\checkmark$ & \\
\hline H9 & $\begin{array}{l}\text { Yapısal güçlendirmenin yenilikçi iş davranışı üzerindeki etkisinde kariyer tat- } \\
\text { mini aracılık rolü üstlenmektedir. }\end{array}$ & $\checkmark$ & \\
\hline H10 & $\begin{array}{l}\text { Psikolojik güçlendirmenin yenilikçi iş davranışı üzerindeki etkisinde kariyer } \\
\text { tatmini aracılık rolü üstlenmektedir. }\end{array}$ & $\checkmark$ & \\
\hline
\end{tabular}

\section{Sonuç}

Bu çalışmada yapısal ve psikolojik güçlendirmenin kariyer tatmini ve yenilikçi iş davranışı üzerindeki etkisi incelenmiştir. Aynı zamanda değişkenlerle kurulan iki model karşılaştırmalı olarak analiz edilmiştir. Birinci model, yapısal güçlendirmenin kariyer tatmini ve yenilikçi iş davranışı arasındaki ilişki üzerinde psikolojik güçlendirmenin aracılık etkisinin olup olmadığıdır. İkinci model, yapısal ve psikolojik güçlendirmenin yenilikçi iş davranışı üzerinde kariyer tatmininin aracılık etkisinin olup olmadığıdır. Araştırma modellerini test etmek amacıyla, üretim işletmelerinde beyaz yakalı olarak görev yapan çalışanlardan anket yöntemi ile veriler toplanmıştır.

Analizler sonucunda, araştırmanın tüm değişkenleri arasında anlamlı ve pozitif yönlü bir ilişkinin ve etkinin olduğuna ulaşılmıştır. $\mathrm{H} 1, \mathrm{H} 2, \mathrm{H} 3$, H4 ve $\mathrm{H} 5$ hipotezleri kabul edilmiştir. Bu sonuçlara göre, kendisini yapısal ve psikolojik olarak güçlendirilmiş hisseden bir çalışanın, kariyer tatmini ve yenilikçi iş davranışı yüksek olmaktadır. Psikolojik açıdan güçlendirilmiş hisseden çaıışanların örgütlerinde yenilikçi iş davranışı gösterme eğilimde olduğu tespit edilmiştir. Çalışanların örgütlerde yetki ve sorumluluklarının artması var olan problemlerle yüzleşmeleri anlamına gelmektedir. Aynı zamanda yeni olması gereken her neyse o şeyi geliştirmek için yenilikçi davranış sergilemek zorundadır. Bu durum ile baş etmek, çalışanların farklı düşünmelerine neden olabilir. Bu sadece örgütsel problemler için değil her açıdan değerlendirilmesi gereken bir süreçtir. Rekabet ortamında sürdürülebilir olmak için yöneticilerin ve çalışanların diğerlerinden farklı düşünmeleri gerekmektedir. Çalışanı bu duruma sevk eden yollardan birisi de onlara örgütlerde hem yapısal hem de psikolojik olarak güçlendirme algısı oluşturulmasıdır.

Çalışmanın örnekleminin beyaz yakalı çalışanlar olduğu düşünülürse güçlendirme algılarının kariyer tatmini üzerinde de etkisinin olduğu görülmektedir. İnsan kaynakları uygulamaları burada önem arz etmektedir. Örgütlerin çalışanlarına, örgüt içerisinde statü ve güç anlamında kariyer olanakları sunmaları önemlidir. Bu sonucun, uygulayıcıların üzerinde mutlaka durmaları gereken ve uygulamaya yansıtmaları gereken önemli bir sonuç olduğu söylenebilir. Sonuç olarak yüksek güçlendirme algısına sahip olan çalışanların kariyerlerinden tatmin olacakları ve yenilikçi iş davranışını gösterebilecekleri söylenebilir. 
Araştırmanın birinci modelinde, psikolojik güçlendirmenin yapısal güçlendirme ile kariyer tatmini ve yenilikçi iş davranışı arasında kısmi aracılık rolünün olduğu tespit edilmiştir. H6 ve H7 hipotezleri kabul edilmiştir. Bu sonuca göre, yapısal anlamda güçlendirilmiş çalışanın aynı zamanda bilişsel süreçte psikolojik olarak güçlendiğini hissetmesi, kendini bu konuda motive etmesi, hem kariyer tatmini hem de yenilikçi iş davranışı göstermelerine olumlu katkı sağlamaktadır. Araştırmanın ikinci modelinde, yapısal ve psikolojik güçlendirme ile yenilikçi iş davranışı arasında kariyer tatmininde aracılık rolü olduğu tespit edilmiştir. $\mathrm{H} 8, \mathrm{H} 9$ ve $\mathrm{H} 10$ hipotezleri kabul edilmiştir. Her iki modelde aracılık etkileri üzerine kurulan hipotezler kabul olmuştur. Her iki modelde incelendiğinde, güçlendirme algısının çalışan davranışları, algıları ve duyguları üzerinde pozitif bir etkiye sahip olduğu tespit edilmiştir.

Araştırmada çıkan sonuçlar yapılan çalışmalarla örtüşmektedir. Örneğin, Tolay ve arkadaşları (2012), yapısal güçlendirmenin psikolojik güçlendirmeye doğrudan, pozitif ve güçlü şekilde etkilediği sonucuna ulaşmışlardır, bu sonuç araştırmamızın H1 hipotezini desteklemektedir. Dan ve arkadaşları (2018), yapısal güçlendirme, kariyer tatmini ve yenilikçi iş davranışı arasında pozitif bir ilişki olduğunu ve yapısal güçlendirmenin yenilikçi iş davranışını pozitif olarak etkilediğini tespit etmişlerdir, bu sonuç H5 hipotezini desteklemektedir, Dan ve arkadaşlarının çalışmalarında ortaya koydukları ilişki sonucuna ilave olarak bu araştırmada etki analizine de yer verilmiştir, bu sonuç literatüre bir katkı olarak değerlendirilebilir. Knol ve van Linge (2009), yapısal ve psikolojik güçlendirmenin yenilikçi iş davranışını pozitif ve anlamlı bir şekilde etkilediğini ve psikolojik güçlendirmenin yapısal güçlendirme ve yenilikçi iş davranışı arasında aracılık etkisi olduğunu tespit etmişlerdir, bu sonuç $\mathrm{H} 5, \mathrm{H} 3$ ve $\mathrm{H} 7$ hipotezini desteklemektedir. Haiyan ve arkadaşları (2016), psikolojik güçlendirmenin kariyer tatmini ve kariyer yetkinlikleri ile pozitif ilişkili olduğu sonucuna ulaşmışlardır, sonuç $\mathrm{H} 2$ hipotezi için değerlendirilebilir ancak araştırmacıların sonucu değişkenler arasındaki ilişkiyi ortaya koymaktadır, bu araştırmada etki analizine de yer verilmiştir, elde edilen sonuç literatüre bir katkı olarak değerlendirilebilir. Yapılan çalışmalarla desteklenmeyen hipotezlerin literatüre katkı sağlayacağı ifade edilebilir.

Araştırma sonuçları yapısal güçlendirme ve psikolojik güçlendirmenin kariyer tatmini ile yenilikçi iş davranışını arttırmadaki önemi kanıtlar niteliktedir. Bunun yanı sıra çalışanlara yetki ve sorumluluk vermek yani onlara güvenmek ve örgüt ortamlarında onları güçlendirmek hem çalışanlara hem örgüte katkı sağlamaktadır. Bu çalışma çalışan güçlendirilmesi, yenilikçi davranışlar ve kariyer konularında gelecekteki araştırmalar için bir temel oluşturabilir. Son olarak araştırmanın sadece üretim sektöründe çalışanlardan oluşması bu araştırmanın sınırlılıklarındandır. Çalışmanın farklı sektörlerde, daha büyük örneklemler üzerinde tekrarlanması daha genellenebilir sonuçlara ulaşılmasını mümkün kılabilir. İleride yapılacak araştırmalar için bu kısıtların giderilmesi tavsiye edilebilir. 


\section{Kaynaklar}

Aydın, Burcu (2016). The Mediating Role of Psychologcal Empowerment on the Relationship between Creative Climate and Innovative Work Behavior: The Case of Employees of Various Sectors in Turkey, Journal of Behavior at Work JB@W Vol. 1, No.1: 74-84.

Bilal, Bin Saeed; Bilal Afsar; Sadia Cheema; Farheen Javed (2019), “Leader-member exchange and innovative work behavior: The role of creative process engagement, core self-evaluation, and domain knowledge", European Journal of Innovation Management, Vol. 22, No. 1: 105-124.

Baron, M. Reuben; Kenny, A. David (1986), "The Moderator-Mediator Variable Distinction in Social Psychological Research: Conceptual, Strategic, and Statistical Considerations", Journal of Personality and Social Psychology, Vol. 51, No. 6: 1173-1182.

Barutçugil, İsmet (2004), Stratejik Insan Kaynakları Yönetimi, İstanbul: Kariyer Yayıncılık.

Cai Wenjing; Lysova I. Evgenia; Khapova, N. Svetlana; Bossink, A. G. Bart (2018), "Servant Leadership and Innovative Work Behavior in Chinese High-Tech Firms: A Moderated Mediation Model of Meaningful Work and Job Autonomy", Frontiers in Psychology, Vol. 9, No. 3: 1767, 1-13.

Calvo, Juan-Carlos Ayala; Garcia, Guadalupe Manzano (2018), "Hardiness As Moderator Of The Relationship Between Structural And Psychological Empowerment On Burnout in Middle Managers", Journal of Occupational and Organizational Psychology, No. 91: 362-384.

Conger, A. Jay; Kanungo, N. Rabindra (1988), "The empowerment process: Integrating theory and practice", Academy of Management Review, Vol.,13, No. 3: 471-482.

Çalışkan, Abdullah (2013), “iç̧ Odaklı Örgüt Kültürünün Yenilikçi Davranışa Etkisinde Personel Güçlendirmenin Aracılık Rolü", "Işs, Güç" Endüstri Iliş̧kileri ve Insan Kaynakları Dergisi, C. 15, S. 1: 88-112.

Çalışkan, C. Sezer (2011), "Çalışanların Psikolojik Güçlendirme Algıları Üzerinde İşyeri Arkadaşlıkları ve Örgütsel illetişimin Etkisi”, Ç.Ü. Sosyal Bilimler Enstitüsü Dergisi, C. 20, S. 3: 77-92.

Çavuş, Mustafa, Fedai; İmadoğlu, Tuğba (2017), “İnsan Kaynakları Yönetimi Uygulamaları Kariyer Tatmini ve İ̧̧ Performansını Etkiler mi?”, International Journal of Academic Value Studies (Javstudies), Vol. 3, No. 12: 98-103.

Çokluk, Ömay; Şekercioğlu, Güçlü ve Büyüköztürk, Şener (2014), Sosyal Bilimler Iç̧in Çok Değişkenli İstatistik: SPSS ve LISREL uygulamaları. Ankara: Pegem.

Dan, Xin; Xu, Suhuan; Liu, Jingying; Hou, Ruonan; Liu, Yanhui; Ma, Hongwen (2018), "Relationships Among Structural Empowerment, Innovative Behaviour, Self-Efficacy, And Career Success in Nursing Field in Mainland China", International Journal of Nursing Practice, Vol. 24, No. 5: 1-9.

Derin, Neslihan (2018), "Kuruma Duyulan Psikolojik Sahiplenme İle Yenilikçi İş Davranışı Arasındaki İlişkide Sanal Kaytarmanın Düzenleyici Rolü”, Hacettepe Üniversitesi Iktisadi ve Idari Bilimler Fakültesi Dergisi, C. 36, S. 1: 63-81.

Erbay, Ö. Elif; Turgut, Tülay (2015), "Yapısal Güçlendirme ve Örgütsel Özdeşleşme Arasındaki İlişkide Psikolojik Güçlendirmenin Ara Değişken Etkisi”, Marmara Üniversitesi iiBF Dergisi, C. XXXVII, S. II: 261-284.

Erdem, Haluk; Gökmen, Yunus; Türen, Ufuk (2016), “Psikolojik Güçlendirme Boyutlarının İş Performansı Üzerine Etkisinde Örgütsel Bağlılığın Aracılık Rolü: Görgül Bir Araştırma”, Doğuş Üniversitesi Dergisi, C. 17, S. 2: 161-176.

Garcia-Sierra, Rosa; Fernandez-Castro, Jordi (2018), "Relationships Between Leadership, Structural Empowerment, And Engagement in Nurses, Journal Of Advanced Nursing, No. 74: 2809-2819.

Greenhaus, H. Jeffrey; Parasurman, Saroj; Wormley, M. Wayne (1990), "Effects of Race on an Organiztional Experiences, Job Performans Evaluations, and Career Outcomes", Academy of Management Journal, Vol. 33, No. 1: 64-86.

Gümüşlüoğlu, Lale; Karakitapoğlu-Aygün, Zahide (2010), "Bilgi Çalışanlarının Adalet ve Güçlendirme Algılarının Örgüte, Lidere ve İşe Bağılık Üzerindeki Etkileri”, Türk Psikoloji Dergisi, C. 25, S. 66: 21-36.

Gürkan, Güney, Çetin; Koçoğlu, Merve (2014), "Yaratıcı Örgüt İkliminin Kariyer Tatmini Üzerine Etkisinde Duygusal Bağlılığın Aracı Değiş̧ken Rolü: Türkiye'de Bir Vakıf ve Bir Devlet Üniversitesinde Karşılaştırmalı Bir Araştırma", Ulus/ararası Sosyal Araştırmalar Dergisi, C. 7, S. 29: 588-602.

Haiyan, Kong; Sun, Ning; Yan, Qi (2016), “New generation, psychological empowerment: can empowerment lead to career competencies and career satisfaction?", International Journal of Contemporary Hospitality Management. Vol. 28, No. 11: 2553-2569.

Hjalager, Anne-Mette (2002), "Repairing Innovation Defectiveness in Tourism", Tourism Management, Vol. 23, No. 5: 465-474. 
Hjalager, Anne-Mette (2010), “A Review of Innovation Research in Tourism”, Tourism Management, Vol. 31, No. 1: 112.

Jiang, J. James; Klein, Gary; Balloun, L. Joseph (2001), "The Joint Impact of Internal and External Career Anchors on Entry-Level IS Career Satisfaction", Information \& Management, No. 39: 31-39.

Kale, Emine (2019), "Proaktif kişilik ve kontrol odağının, kariyer tatmini ve yenilikçi iş davranışına etkisi", Journal of Tourism Theory and Research, Vol. 5, No. 2: 144-154.

Kanter, M. Rosabeth (1993), Men and Women of the Corporation (2nd ed.). New York: Basic Books.

Kerse, Gökhan ve Karabey, Canan, Nur (2014), “Personel Güçlendirme İle Bireyin Yaratıcılık Algısı Arasındaki İlişki: Bankacılık Sektöründe Bir Uygulama”, Akdeniz i.i.B.F. Dergisi, S. 29: 22-41.

Knol, Jeannette; Van Linge, Roland (2009), “Innovative Behaviour: The Effect of Structural and Psychological Empowerment on Nurses", Journal of Advanced Nursing, Vol. 65, No. 2: 359-370.

Laschinger, S. Heather; Finegan, Joan; Shamian, Judith; Wilk, Piotr (2001), "Impact of Structural and Psychological Empowerment on Job Strain in Nursing Work Settings: The Expanding Kanter's Model”, Journal of Nursing Administration, Vol. 31, No. 5: 260-272.

O’Brien, L. Janice (2010), “Structural Empowerment, Psychological Empowerment and Burnout in Registered Staff Nurses Working in Outpatient Dialysis Centers" Degree of Doctor of Philosophy, New Jersey, The State University of New Jersey.

Orgambídez-Ramos, Alejandro; Borrego-Alés, Yolanda (2014), “Empowering Employees: Structural Empowerment as Antecedent of Job Satisfaction in University Settings", Psychological Thought, Vol. 7, No. 1: 28-36.

Örnek, Ali, Şahin; Ayas, Siyret (2015), "Entelektüel Sermaye ile Yenilikçi İş Davranışının İşletme Performansına Etkisi: Bilişim Sektörü Uygulaması”, Dokuz Eylül Üniversitesi Iş̧letme Fakültesi Dergisi, C. 16, S. 2: 91-116.

Örücü, Edip; Çınar, Binnaz (2019), “Pozitif Psikolojik Sermayenin Yenilikçi Davranış Üzerindeki Etkisi: Bankacılık Sektöründe Bir Araştırma", Anemon Muş Alparslan Üniversitesi Sosyal Bilimler Dergisi, C. 7, S. 2: 287-299.

Prabowo, Rahadi; Mustika, Dwi, Martina; Sjabadhyni, Bertina (2018), “How a Leader Transforms Employees' Psychological Empowerment Into Innovative Work Behavior", Psychological Research on Urban Society, Vol. 1, No. 2: 9099.

Polatcı, Sema; Özçalık, Fatih (2013), "Yapısal ve Psikolojik Güçlendirmenin İşyeri Nezaketsizliği ve Tükenmişliğe Etkisi”, işletme Bilimi Dergisi, C. 1, S. 1: 17-34.

Sabuncuğlu, Zeyyat (2012), Uygulama Örnekleriyle Insan Kaynakları Yönetimi, İstanbul: Beta.

Sağlam Arı, Güler; Ergeneli, Azize (2003), “Psikolojik Güçlendirme Algısı Ve Bazı Demografik Değişkenlerin Örgütsel Bağlılığa Etkisi", H. Ü. İktisadi ve Idari Bilimler Fakültesi Dergisi, C. 21, S. 1: 129-149.

Sakal, Önder; Yıldız, Sebahhattin (2015), "Bireycilik ve Toplulukçuluk Değerleri, Kariyer Çapaları ve Kariyer Tatmini İlişkisi”, Journal of Yasar University, C. 10, S. 40: 6612-6623.

Schumpeter, A. Joseph (1939). Business Cycles A Theoretical, Historical, And Statistical Analysis Of The Capitalist Process, New York, London: McGraw-Hill Book Company.

Śledzik, Karol (2013), Schumpeter's View on Innovation and Entrepreneurship (April 29, 2013). Management Trends in Theory and Practice, (ed.) Stefan Hittmar, Faculty of Management Science and Informatics, University of Zilina \& Institute of Management by University of Zilina.

Schuh Sebastian, C.; Zhang Xin-an; Morgeson Frederick, P.; Tian Peng; van Dick Rolf (2018), “Are You Really Doing Good Things in Your Boss's Eyes? Interactive Effects Of Employee Innovative Work Behavior And Leader-Member Exchange On Supervisory Performance Ratings", Human Resource Management, No. 57: 397-409.

Scott, G. Susanne; Bruce, A. Reginald (1994), "Determinants of Innovative Behavior: A Path Model of Individual Innovation in the Workplace", Academy of Management Journal, Vol. 37, No. 3: 580-607.

Spreitzer, M. Gretchen (1995), "Psychological Empowerment in the Workplace: Dimensions, Measurement, and Validation", The Academy of Management Journal of Manegement Journal, Vol. 38, No. 5: 1442-1465.

Sürvegül, Alca; Tolay, Ebru; Topoyan, Mert (2013), Yapısal Güçlendire ve Psikolojik Güçlendirme Ölçeklerinin Geçerlilik ve Güvenilirlik Analizleri, Journal of Yasar University, C. 8, S. 31: 5371-5391.

Spurk, Daniel; Abele, E. Andrea; Volmer, Judith (2011), "The Career Satisfaction Scale: Longitudinal Measurement Invariance and Latent Growth Analysis", Journal of Occupational and Organizational Psychology, No. 84: 315-326 


\section{Eskişehir Osmangazi Üniversitesi ïiBF Dergisi}

Thomas, W. Kenneth; Velthouse, A. Betty (1990), Cognitive Elements Of Empowerment: An Interpretive Model Of Intrinsic Task Motivation. Academy of Management Review, Vol. 15, No. 4: 666-681.

Tolay, Ebru; Sürgevil, Olca; Topoyan, Mert (2012), “Akademik Çalışma Ortamında Yapısal ve Psikolojik Güçlendirmenin Duygusal Bağlııı ve İş Doyumu Üzerindeki Etkileri”, Ege Akademik Bakış, C. 12, S. 4: 449-465.

Toplu, Duygu; Akça, Meltem (2013), “Öğrenen Organizasyonun Psikolojik Güçlendirme Üzerindeki Etkisi: Kamu Sektöründe Bir Araştırma”, Istanbul Ticaret Üniversitesi Sosyal Bilimleri Dergisi, C. 12, S. 23: 221-235.

Turgut, Ercan; Beğenirbaş, Memduh (2013), "Çalışanların Yenilikçi Davranışları Üzerinde Sosyal Sermaye Ve Yenilikçi İklimin Rolü: Sağlık Sektöründe Bir Araştırma”, KHO Bilim Dergisi, C. 23, S. 2: 101-124.

Ulukök, Esra; Akın, Adnan (2016), "işskoliklik ve Kariyer Tatmini”, Uluslararası Bilimsel Araştırmalar Dergisi, C.1, S. 2: 6271.

Yüksel, ìhsan (2005), "İş-Aile Çatışmasının Kariyer Tatmini, İş Tatmini ve İş Davranışları ille İlişkisi”, Atatürk Üniversitesi iktisadi ve Idari Bilimler Dergisi, C. 19, S. 2: 301-314. 


\section{Extended Summary}

\section{Effects Of Structural and Psychological Empowerment on Career Satisfaction and Innovative Work Behavior}

This study was designed to determine the relationship and impact of structural and psychological empowerment on career satisfaction and innovative work behavior. In order to test the research model in Turkey sample, using a survey method, data is collected from the white-collar employees in some production businesses. As a result of the correlation analysis, it was found that there were positive and significant relationships between the variables. As a result of the regression analysis, it was determined that structural and psychological empowerment affected career satisfaction and innovative work behaviour positively. After determining these effects, the first model was analyzed to determine whether psychological empowerment played a mediating role in the impact of structural empowerment on career satisfaction and on innovative work behaviour. Then, the second model was analyzed to determine whether career satisfaction plays a mediating role in the impact of structural and psychological empowerment on innovative work behavior. It is thought that the research will contribute to both practitioners and employees.

In this study, empowerment was examined as structural and psychological empowerment based on the empowerment of employees. Kanter (1993) defined empowerment as "the ability of an individual to utilize the resources available to achieve the goals and to make decisions independently". According to Kanter (1993), structural empowerment was comprised of practices that propose access to information, resources, support and training opportunities in the working environment.This approach, introduced by Conger and Kanungo (1988), was developed by Thomas and Velthouse (1990). Psychological empowerment is the perceptions of whether employees feel empowered (Thomas and Velthouse, 1990). Do these forms of empowerment, structural and psychological empowerment, affect career satisfaction and innovative work behavior? Career means that the employee develops himself/herself, obtains a status in the organizational environment, has power, has a say in his / her work, and takes part in decision-making mechanisms and gains respectability. Career satisfaction refers to individuals' perceptions of the degree to which they achieve their goals and expectations related to their careers in their organizations. Career satisfaction refers to the perceptions of individuals about their careers in the organizations they work in and the degree to which they achieve their goals and expectations (Sakal and Yıldız, 2015). Innovative work behavior includes the process of introducing new ideas, adopting and implementing these ideas (Çalışkan, 2013).

The hypotheses established by the support of the theoretical framework and the studies conducted are as follows:

H1: Structural empowerment meaningful and positive effects psychological empowerment.

H2: Psychological empowerment meaningful and positive effects career satisfaction.

H3: Psychological empowerment meaningful and positive effects innovative work behaviors.

H4: Structural empowerment meaningful and positive effects career satisfaction.

H5: Structural empowerment meaningful and positive effects innovative work behaviors.

H6: Psychological empowerment plays a mediator role in the impact of structural empowerment on career satisfaction.

H7: Psychological empowerment plays a mediator role in the impact of structural empowerment on innovative work behavior.

In this study, it is analyzed whether career satisfaction has a mediating role between structural and psychological empowerment and innovative work behavior. The hypotheses established for this model are the continuation of the hypotheses established for the first model. The hypotheses of this model are as follows:

H8: Career satisfaction meaningful and positive effects innovative work behavior.

H9: Career satisfaction plays a mediator role in the impact of structural empowerment on innovative work behaviour

H10: Career satisfaction plays a mediator role in the impact of psychological empowerment on innovative work behaviour.

Primarily, the effect of structural and psychological empowerment on career satisfaction and innovative work behavior will be determined. Model 1 (mediator role effect of psychological empowerment between structural empowerment and career satisfaction and innovative work behavior) and Model 2 (mediator role effect of career satisfaction between psychological empowerment and structural empowerment and innovative work behavior) will be examined. Firstly, information about samples and scales was given. Then, the data obtained from the sample were analysed for 


\section{Eskişehir Osmangazi Üniversitesi ïiBF Dergisi}

the developed model. After the correlation coefficients were determined, regression analysis and research hypotheses were tested. Based on the findings of the analyses, suggestions were made to the practitioners and the researchers.

The questionnaire used in the research consists of five chapters. In the first four chapters, there are scales related to the research variables and in the last section, there are questions about the demographic characteristics of the participants. A 5-point Likert-type rating was used for all scales. Structural Empowerment Scale: The 18-item scale developed by Laschinger et al. (2001) was used to determine the level of structural empowerment. Psychological Empowerment Scale: The 12-item scale developed by Spreitzer (1995) was used to determine the level of psychological empowerment. Career Satisfaction Scale: The 5-item scale developed by Greenhaus et al. (1990) was used to determine the level of career satisfaction. Innovative Work Behavior Scale: The 6-item scale used by Scott and Bruce (1994) was used to determine the level of innovative work behavior of participants in the study.

As a result of the analysis, it was found that there were a significant and positive relationship and effect among all the variables of the study. The hypotheses $\mathrm{H} 1, \mathrm{H} 2, \mathrm{H} 3, \mathrm{H} 4$, and $\mathrm{H} 5$ were accepted. In the first model of the study, it was observed that the effect of structural empowerment on innovative work behaviour and career satisfaction was not completely eliminated by the introduction of psychological empowerment. Therefore, it is possible to say that psychological empowerment plays a partial mediation role between structural empowerment and innovative work behaviour and career satisfaction. In this case, the hypotheses $\mathrm{H} 6$ and $\mathrm{H} 7$ was also accepted. According to this result, the fact that the structurally empowered employee feels psychological empowerment in the cognitive process, motivating himself in this regard contributes positively to both career satisfaction and innovative work behavior. In the second model of the study, it was found that career satisfaction plays a mediation role between structural empowerment and psychological empowerment and innovative work behaviour. $\mathrm{H} 8, \mathrm{H} 9$ and $\mathrm{H} 10$ hypotheses were accepted. The hypotheses based on mediating effects in both models have been accepted. When both models were analyzed, it was found that empowerment perception had a positive effect on employee behaviors, perceptions, and emotions. 